\title{
Enderun Dergisi
}

Cilt:1 Sayı:2

Gönderiliş Tarihi: 19/04/2017

Kabul Tarihi: 03/05/2017

\author{
THE FALL OF THE OTTOMANS: THE GREAT WAR IN THE MIDDLE EAST \\ By Eugene Rogan
}

Tuğçe GÖÇERDIR ${ }^{1}$

\section{OSMANLI'NIN ÇÖKÜŞÜ: ORTADOĞU'DA BÜYÜK SAVAŞ}

1914-1918 Büyük Savaşı'nda yayınlanan ingilizce kitapların çoğu, belirli nedenlerden dolayı sadece Batı cephesinden olan savaşlara odaklandılar. Doğu cephesini inceleyen çalışmalarda Gelibolu cephesinin ötesine geçemedi. Savaş sırasında Almanya'nın yanında yer alan ve savaş sonunda yenilgiye uğrayan Osmanlı İmparatorluğu açısından kitap güzel bir açıklama getirmektedir. Kitabın yazarı Oxford Üniversitesi'nde öğretim üyeliği yapan Eugene Rogan Ortadoğu'da yıllarını geçirmiş olması münasebetiyle, Türk ve Batı tarihçileri tarafından nadiren ziyaret edilen diğer arşivlerde araştırma yapma konusunda dil yeteneğine sahipti. Kendisine göre yeri geldiğinde gergin yeri geldiğinde esprili bir dile sahip olan eseri jeopolitik ve askeri açıdan iyi bir örnek oluşturmaktadır.

Yüzyılın başlarında Osmanlı İmparatorluğu iç muhalefet ve dış tehditlerle mücadele eder haldeydi. "Avrupa'nın hasta adamı" olarak biliniyordu. Birincil korku, Karadeniz'den Akdeniz'e girmeyi arzulayan Çarlık Rusyası'nın işgaliydi. Savunma için, Türkler, bir İngiliz tersanesi tarafından iki Dreadnaught sınıfı savaş gemisi inşa etmek için yeterli parayı kazınmışlardı. 1914 yılında Savaş'ın çıkmasıyla İngilizler Osmanlı için ürettikleri gemilere el koydular ve Kraliyet Donanmasına dahil ettiler. Uzun süren şikayetler sonrasında sonuç elde edemeyen Türkler Almanlarla ortak bir şekilde savaşa girmeye karar verdi.

Osmanlılar İngiliz ve Fransız kolonilerinde (özellikle Hindistan, Kuzey Afrika ve Mısır) yaşayan yaklaşık 240 milyon Müslüman hakkında ciddi bir yanlış hesaplama yaptı. Almanya'nın propogandasıyla Cihad çağrısında bulundu fakat beklenilen destek gelmedi. Sadece Hintli Müslümanlar savaşta büyük bir gayret göstererek savaştılar.

İngiliz Donanmasının başında bulunan Winston Churchill'in İstanbul'u bir deniz bombardımanı ile ele geçirme planı yaptı. Böylelikle Almanların Hindistan'a olan İngiliz deniz bağlantılarını kesme girişiminde bulunmuş olacaktı. Fakat Churchill'in deniz saldırısı başarısız oldu, bunun üzerine İngiliz kara komutanı General Horatio Herbert Kitchener, Gelibolu yarımadasına on

\footnotetext{
${ }^{1}$ Öğretim Görevlisi, Artvin Çoruh Üniversitesi, tugcegocerdir@artvin.edu.tr
} 
binlerce askeri ile saldırdı. Yazar bu bölümde savaşın korkunç yüzünü 29 sayfa ile anlatmaktadır. Çürüyen cesetler ve korkunç savaş sahneleri üzerinde durmaktadır. Ayrıca savaşın sorumlusu olarak da Churcill'i göstermektedir.

Daha kötü bir senaryo İngilizlerin başına Bağdatın altında yer alan Rut şehrinde geldi. Türkler ve diğer ülkelerden gelen özellikle de Hintli Müslümanlar tarafından çevrili olan bu şehirde İngilizler ağır yenilgiye uğradılar. On beş bin İngiliz askeri esir alındı. İngiliz askerlerinin cesetleri ağaçlara asıldı. Öyle ki yazara göre İngilizlerin daha önce bir savaşta bu kadar teslim olma oranı da görülmemişti.

Yiyecek sıkıntı çeken Osmanlı ordusu at eti yemeye başladı (Hintli Müslümanlar savaşta at eti yemeyi istemedikleri için de sağlık problemleri yaşadılar). Bütün zorluklara rağmen başarılar elde eden Osmanlı İmparatorluğu'nun görkemli zaferine kabile ve dini ayrımlar gem vurdu. İngiliz İstihbarat Birlikleri samimiyetten uzak vaatlerle Arapları Osmanlı İmparatorluğu'na karşı kışkırttılar. Bağımsızlık hayaliyle ihanet eden Araplar savaşın seyrini değiştirdi. Ancak sonuç olarak bağımsızlıklarını kazanma yerine herbiri Avrupalı ülkelerin sömürgesi oldu. Suriye ve Lübnan Fransızlara teslim edildi. Mısır İngiliz yönetimi altında kaldı. Filistin'e Yahudiler yerleştirildi.

Yazara göre bu Savaş sonrası imzalanan anlaşmalar barışa hizmet etmekten ziyade İngiltere ve Fransa'nın topraklarını genişletme arzusu içerisinde gerçekleştirildi. Yazar kitabında bu anlaşmalardan dolayı Ortadoğu'da aralıksız kargaşanın devam ettiği kanaatini taşımaktadır. 